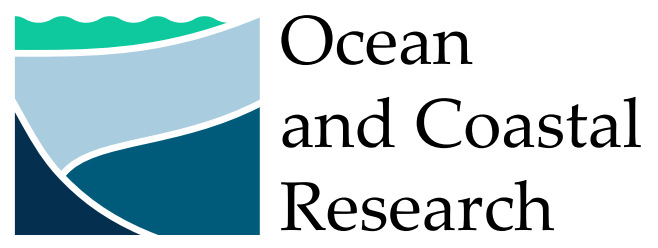

\title{
The spread of the introduced ascidians Ciona robusta Hoshino \& Tokioka, 1967 and Rhodosoma turcicum (Savigny, 1816) in the southwestern Atlantic
}

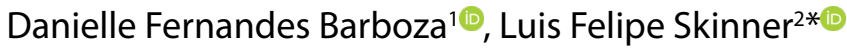 \\ 1 Universidade do Estado do Rio de Janeiro, Laboratório de Ecologia e Dinâmica Bêntica Marinha (Rua Francisco Portela 1470, sala 172, \\ Patronato, São Gonçalo - 24435-005 - Rio de Janeiro - RJ - Brazil) \\ ${ }^{2}$ Universidade do Estado do Rio de Janeiro, Programa de Pós graduação em Oceanografia - (Rua São Francisco Xavier, 524 - sala 4018/ \\ bloco E - Maracanã - Rio de Janeiro - 22550-013 - RJ - Brazil) \\ *Corresponding author: Iskinner@uerj.br
}

\section{Abstract}

New records of the introduced solitary ascidians, Ciona robusta and Rhodosoma turcicum, have been added to the southwestern Atlantic Ocean, from Cabo Frio to llha Grande Bay, Brazil, in surveys conducted since 2009. Both species occurred on natural and artificial substrates, in predator-protected habitats, and regions close to harbors or other maritime activities. The distribution of Ciona robusta was related to water temperature, influenced by upwelling intensity and temperatures below $25^{\circ} \mathrm{C}$, while $R$. turcicum was not sensitive to the range of recorded water temperatures. The occurrence of both species on sites close to maritime terminals suggests vessels as potential vectors.

Descriptors: Ascidiacea; Marine fouling; Introduced species; Marine activities.

\section{INTRODUCTION}

Marine bioinvasions have been recorded globally and have increased in recent decades in terms of the numbers of recorded species and numbers of scientific papers published (Seebens et al., 2013; Dias et al., 2019). Invasive species (IS) and nonindigenous species (NIS) have been identified as being responsible for reducing diversity in invaded regions, leading to local extinctions, and causing impacts on economic activities (Creed et al., 2017; O'Brien et al., 2017; Blackburn et al., 2019). Academic discussions concerning those issues are continually increasing (Junqueira, 2013; Boltovskoy et al., 2018; Fowler et al., 2020). Awareness of the importance of ascidians as invasive species is growing worldwide (Carlton and

Submitted: 03-September-2020

Approved: 01-April-2021

Editor: Rubens M. Lopes

Associate Editor: Abilio Soares-Gomes

(c) (i)

() 2021 The authors. This is an open access article distributed under the terms of the Creative Commons license.
Eldredge, 2009; Zhan et al., 2015; Colarusso et al., 2016).

Eutrophication (Marins et al., 2010; Crooks et al., 2011), aquaculture facilities (McKindsey et al., 2007; Rocha et al., 2009), and harbor and shipping operations (Darbyson et al., 2009; Grey, 2010) have been indicated as important influences in increasing their spread. However, NIS introduction and spread are also subjected to limiting factors. Predation by fish (Marins et al., 2009; Dumont et al., 2011; Dias et al., 2013; Roth et al., 2017) and competition with the local fauna (Paetzold et al., 2012) are two biological factors that can regulate invasiveness, while environmental factors (such as temperature) can act as selective forces that prevent the establishment and persistence of invasive species. Therefore, environmental and biological factors will delimit species niches and are determinants for successful bioinvasions (Granot et al., 2017).

Ascidians can be found in many different habitats, and the photonegative behavior of their larvae 
favors their occurrence in crevices or under rocks, more protected from predation and sedimentation (Millar, 1971; Lambert, 2005). Communities that settle on artificial substrates have often been found to be different from those encountered on natural surfaces (Perkol-Finkel et al., 2006). Artificial substrates are common in ports and marinas and serve as gateways for species introductions (Lambert, 2005; Ignacio et al., 2010). Surveys of invasive species must, therefore, use specific methodologies for data collection (Kakkonen, 2019).

The species Ciona robusta Hoshino \& Tokioka, 1967 and Rhodosoma turcicum (Savigny, 1816) are considered invasive in many parts of the world. Both species have been recorded in Brazil but studies indicated that they are susceptible to native predators (Marins et al., 2009; Skinner et al., 2013). At least 14 other non-indigenous ascidian species have likewise been recorded in Rio de Janeiro State (Rocha and Costa, 2005; Marins et al., 2010; Granthom-Costa et al., 2016; Skinner et al., 2016, Oricchio et al., 2019).

Ciona robusta (formely identified on Brazil as C. intestinalis) was reported by Millar (1958) in São Sebastião (São Paulo state), and later in Guanabara Bay (Rio de Janeiro state), by Costa (1969) in 1958 and 1961, and elsewhere in Rio de Janeiro (Marins et al.,
2009) and São Paulo (Rocha, 1995; Rocha and Bonnet, 2009; Dias et al., 2013; Vieira et al., 2012) coasts in the following decades. Rhodosoma turcicum has been recorded from the states of Bahia (Rocha et al., 2012a) and Rio de Janeiro (Skinner et al., 2013).

We describe here the current distribution of Ciona robusta and Rhodosoma turcicum in coastal areas of Rio de Janeiro ( $250 \mathrm{~km}$ in total), highlighting the importance of sea temperature on their distributions. We also discuss the current knowledge on possible transport vectors and their spreading along the southeast Brazilian coast.

\section{METHODS}

This study was performed with research authorization from the Instituto Estadual do Ambiente - INEA (Auth. \#057/2011 and 025/2017), RESEX Arraial do Cabo (ICMBio Auth. \#25024), and Estação Ecológica Tamoios (ICMBio - Auth. \#36194).

\section{Study Area}

The present study was conducted within the coastal transition zone between Tropical and Warm Temperate regions (Spalding et al., 2007) in Rio de Janeiro State (Figure 1A and 1B). The area has intense maritime activities like shipping, harbor, oil industry

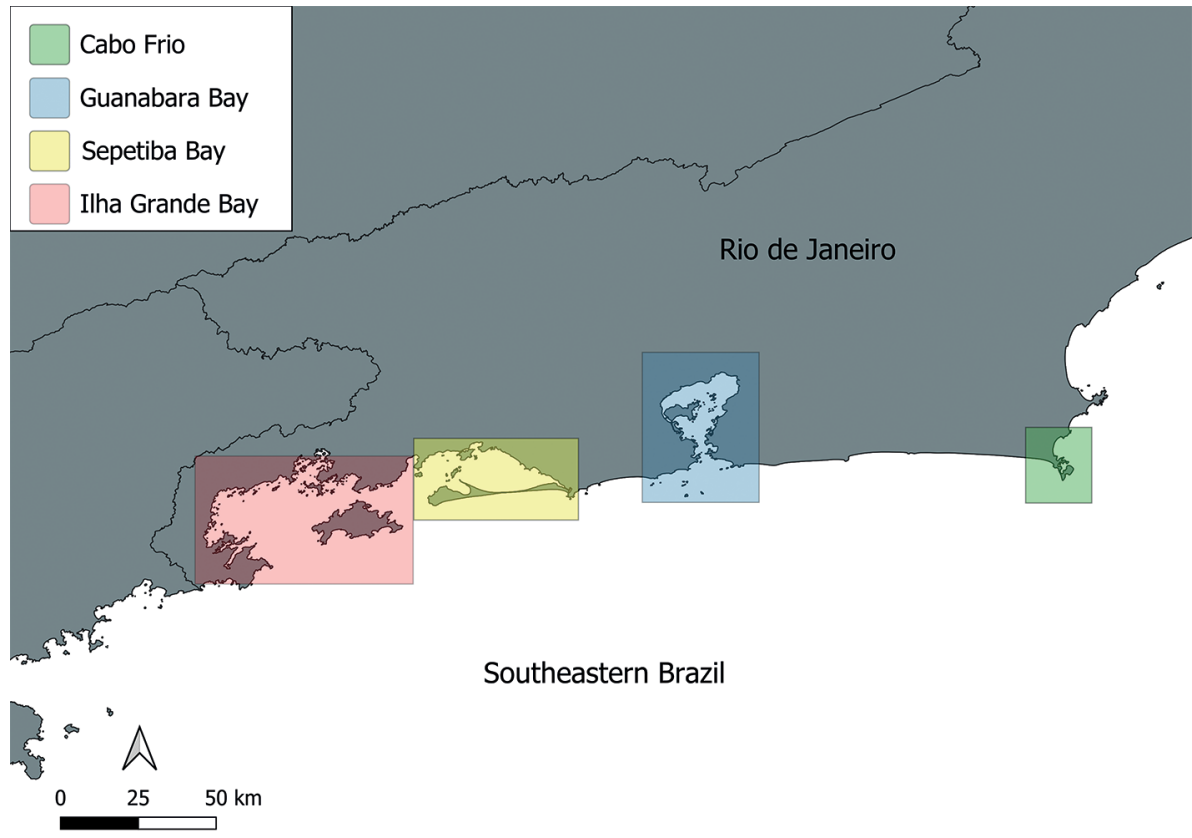

Figure 1. Surveyed areas on the coast of Rio de Janeiro State, Brazil: Cabo Frio (green), Guanabara Bay (blue), Sepetiba Bay (yellow), and Ilha Grande Bay (red). 
and other nautical activities, such as tourism, fishing, and coastal development (Silva et al., 2018; INEA, 2015; Ignacio et al., 2010). The climate is considered tropical humid, with a rainy season from October to April, and a dry season from May to September. Despite that general pattern, rainfall can vary greatly along the coast, mainly due to the proximity of the Serra do Mar Mountains, with average annual rainfall rates varying from 800 to 2,100mm (INEA 2015; Coe et al., 2007). There is a seasonal upwelling, which is stronger close to Cabo Frio, becoming weaker close to Ilha Grande Bay (Valentin, 2001; Creed et al., 2007).

\section{WATER MONITORING - SEA SURFACE TEMPERATURES}

Sea surface temperatures (SST) were measured using IButton ${ }^{(\mathrm{R})}$ sensors programmed to record every hour at Cabo Frio and Ilha Grande Bay (at two sites in the latter: Dois Rios and Ponta Leste). The sensors were accommodated inside falcon tubes (to protect them from direct contact with the seawater) and placed at depths of 1-2 m, depending on the site. The shallow positions of the sensors ensured that no effects of water stratification were measured. SST data were aggregated monthly, and mean, and standard deviations were calculated. SST measurements were initiated in 2012 and extended until January 2014 in Cabo Frio and December 2019 in Ilha Grande Bay. Additionally, we extracted monthly SST data from satellite imagery during the period between January 2009 and December 2019 (data provided by NCEP, OISST Version 2, available from https://iridl.Ideo.columbia.edu/maproom/Global/Ocean_Temp), from the Brazilian Navy Oceanographic Buoys Program (PIRATA), and from the National Oceanographic Data Center (BNDO, 2020) for Cabo Frio, covering 20092010, 2012-2013, and 2016-2018.

\section{SAMPLING}

We employed two sampling strategies: on artificial experimental structures (Marins et al., 2009; Kremer and Rocha, 2011; Skinner et al., 2013) and by active SCUBA or free diving searches. Our approach was similar to Kakkonen et al. (2019), which emphasize habitats favoring ascidian recruitment.

\section{Artificial structures}

Granite plates $(21 \times 12 \mathrm{~cm})$ and sandwich black polyethylene plates $(15 \times 15 \mathrm{~cm})$, sensu Kremer and
Rocha (2011) were used to collect ascidians within protected cages, needed to prevent fish predation on ascidian recruits (Marins et al., 2009; Skinner et al., 2013). The experimental units were immersed $1 \mathrm{~m}$ below the surface at 11 sites positioned in the study areas: Cabo Frio (at Itajuru Inlet, Forno Harbor, and Cabo Frio Island); Guanabara Bay (Urca and Praia Vermelha); Sepetiba Bay (Junqueira and Guaíba Island); and Ilha Grande Bay (Piraquara de Fora, Praia do Anil, Ponta Leste, Abraão, and Dois Rios). Polyethylene plates were installed only at sites off Ilha Grande (Table 1).

\section{SCUBA AND FREE DIVING}

Exploratory scuba diving was undertaken for periods of 50 minutes each, actively searching for solitary ascidians on potentially predator-protected substrates such as holes, caves, or under boulders (Rocha, 1995). Those searches were performed at 26 sites at Ilha Grande Bay and two sites at Cabo Frio (Table 1). Free diving was used at some sites with submerged artificial structures; no scuba diving was undertaken in Guanabara Bay or Sepetiba Bay due to low water visibility.

\section{Data ANALYsis}

Mean monthly SST was calculated from daily data for Cabo Frio and Ilha Grande Bay collected by Ibutton ${ }^{\circledR}$ sensors and buoys. Satellite SST was retrieved to gain a wide temporal and regional perspective. Mean SST values $(<$ $25.0^{\circ} \mathrm{C}$ and $>25.1^{\circ} \mathrm{C}$ ) were used in combination with records of Ciona robusta and Rhodosoma turcicum in the selected temperature ranges to perform a square Fisher analysis (Underwood 1997) testing the hypothesis that temperature influences Ciona robusta distribution, but not Rhodosoma turcicum occurrences. The SST value of $25^{\circ} \mathrm{C}$ was chosen as the upper physiological limit of survival for C. robusta (Caputi et al., 2015; Rocha et al., 2017; Kim et al., 2019). The physiological temperature limits for R. turcicum are unknown, but due to its tropical distribution the species may thrive in water temperatures higher than $22^{\circ} \mathrm{C}$, as suggested by Shenkar and Loya (2009).

\section{RESULTS}

\section{WATER TEMPERATURE MONITORING}

SST data from lbutton ${ }^{\circledast}$ sensors, buoys, and satellites indicated large SST variations between seasons, years, and monitoring methods (Figure 2). Satellite 
Table 1. Survey sites, including geographical coordinates, survey methods, and types of substrates sampled.

\begin{tabular}{|c|c|c|c|c|c|}
\hline Surveyed site & Region & Latitude & Longitude & Survey methods & substrate \\
\hline Meros Island & Ilha Grande Bay & $23^{\circ} 11^{\prime} \mathrm{S}$ & $44^{\circ} 34^{\prime} \mathrm{W}$ & Scuba & Natural \\
\hline Ratos Island & Ilha Grande Bay & $23^{\circ} 11^{\prime} \mathrm{S}$ & $44^{\circ} 36^{\prime} \mathrm{W}$ & Scuba & Natural \\
\hline Ponta do Arpoá & Ilha Grande Bay & $23^{\circ} 12^{\prime} \mathrm{S}$ & $44^{\circ} 36^{\prime} \mathrm{W}$ & Scuba & Natural \\
\hline Deserta Island & Ilha Grande Bay & $23^{\circ} 13^{\prime} \mathrm{S}$ & $44^{\circ} 33^{\prime} \mathrm{W}$ & Scuba & Natural \\
\hline Mantimento Island & Ilha Grande Bay & $23^{\circ} 11^{\prime} S$ & $44^{\circ} 39^{\prime} \mathrm{W}$ & Scuba & Natural \\
\hline Paraty Mirim & Ilha Grande Bay & $23^{\circ} 14^{\prime} \mathrm{S}$ & $44^{\circ} 37^{\prime} \mathrm{W}$ & Scuba, granite plate & Natural, Artificial \\
\hline Ponta Leste & Ilha Grande Bay & $23^{\circ} 3^{\prime S}$ & $44^{\circ} 14^{\prime} \mathrm{W}$ & $\begin{array}{l}\text { Scuba, Granite and } \\
\text { polyethylene plate }\end{array}$ & $\begin{array}{l}\text { Natural an } \\
\text { Artificial }\end{array}$ \\
\hline Anil beach & Ilha Grande Bay & $23^{\circ} 0.5^{\prime} \mathrm{S}$ & $44^{\circ} 18^{\prime} \mathrm{W}$ & Granite plate & Artificial \\
\hline Bonfim beach & Ilha Grande Bay & $23^{\circ} 1^{\prime} \mathrm{S}$ & $44^{\circ} 19^{\prime} \mathrm{W}$ & Scuba & Natural \\
\hline Piraquara de Fora & Ilha Grande Bay & $23^{\circ} 1^{\prime} \mathrm{S}$ & $44^{\circ} 26^{\prime} \mathrm{W}$ & Granite plate & Artificial \\
\hline Laje Grande & Ilha Grande Bay & $23^{\circ} 0.8^{\prime} \mathrm{S}$ & $44^{\circ} 15^{\prime} \mathrm{W}$ & Scuba & Natural \\
\hline Sororoca Island & Ilha Grande Bay & $23^{\circ} 2^{\prime} \mathrm{S}$ & $44^{\circ} 9^{\prime} \mathrm{W}$ & Scuba & Artificial \\
\hline Longa Island & Ilha Grande Bay & $23^{\circ} 8^{\prime} \mathrm{S}$ & $44^{\circ} 19^{\prime} \mathrm{W}$ & Scuba, polyethylene plates & Natural, Artificial \\
\hline Sítio Forte Point & Ilha Grande Bay & $23^{\circ} 6^{\prime} \mathrm{S}$ & $44^{\circ} 17^{\prime} \mathrm{W}$ & Scuba, polyethylene plates & Natural, Artificial \\
\hline Bananal Point & Ilha Grande Bay & $23^{\circ} 6^{\prime} \mathrm{S}$ & $44^{\circ} 15^{\prime} \mathrm{W}$ & Scuba & Natural \\
\hline Macacos Island & Ilha Grande Bay & $23^{\circ} 4^{\prime} \mathrm{S}$ & $44^{\circ} 13^{\prime} \mathrm{W}$ & Scuba & Natural \\
\hline Aventureiro & Ilha Grande Bay & $23^{\circ} 11^{\prime} \mathrm{S}$ & $44^{\circ} 18^{\prime} \mathrm{W}$ & Scuba & Natural \\
\hline Tacunduba & Ilha Grande Bay & $23^{\circ} 11^{\prime} \mathrm{S}$ & $44^{\circ} 16^{\prime} \mathrm{W}$ & Scuba & Natural \\
\hline Parnaioca & Ilha Grande Bay & $23^{\circ} 11^{\prime} \mathrm{S}$ & $44^{\circ} 15^{\prime} \mathrm{W}$ & Scuba & Natural \\
\hline Sardinhas Cove & Ilha Grande Bay & $23^{\circ} 11^{\prime} \mathrm{S}$ & $44^{\circ} 12^{\prime} \mathrm{W}$ & Scuba & Natural \\
\hline Amarração Island & Ilha Grande Bay & $23^{\circ} 10^{\prime} \mathrm{S}$ & $44^{\circ} 10^{\prime} \mathrm{W}$ & $\begin{array}{l}\text { Scuba, polyethylene and } \\
\text { granite plates }\end{array}$ & Natural, Artificial \\
\hline Palmeiras Point & Ilha Grande Bay & $23^{\circ} 10^{\prime} \mathrm{S}$ & $44^{\circ} 10^{\prime} \mathrm{W}$ & Scuba & Natural \\
\hline Cavalinho Point & Ilha Grande Bay & $23^{\circ} 11^{\prime} \mathrm{S}$ & $44^{\circ} 10^{\prime} \mathrm{W}$ & Scuba & Natural \\
\hline Jorge Grego Island & Ilha Grande Bay & $23^{\circ} 12^{\prime} \mathrm{S}$ & $44^{\circ} 9^{\prime} \mathrm{W}$ & Scuba, polyethylene plates & Natural, Artificial \\
\hline Santo Antônio rocks & Ilha Grande Bay & $23^{\circ} 10^{\prime} S$ & $44^{\circ} 8^{\prime} \mathrm{W}$ & Scuba & Natural \\
\hline Lopes Mendes & Ilha Grande Bay & $23^{\circ} 11^{\prime} \mathrm{S}$ & $44^{\circ} 7^{\prime} \mathrm{W}$ & Scuba, polyethylene plates & Natural \\
\hline Caxadaço Point & Ilha Grande Bay & $23^{\circ} 10^{\prime} \mathrm{S}$ & $44^{\circ} 9^{\prime} \mathrm{W}$ & Scuba & Natural \\
\hline Castelhanos & Ilha Grande Bay & $23^{\circ} 9^{\prime} \mathrm{S}$ & $44^{\circ} 5^{\prime} \mathrm{W}$ & Scuba, polyethylene plates & Natural, Artificial \\
\hline Palmas Island & Ilha Grande Bay & $23^{\circ} 8^{\prime} \mathrm{S}$ & $44^{\circ} 6^{\prime} \mathrm{W}$ & Scuba & Natural \\
\hline Abraão & Ilha Grande Bay & $23^{\circ} 8^{\prime} \mathrm{S}$ & $44^{\circ} 10^{\prime} \mathrm{W}$ & Granite plate & Artificial \\
\hline Junqueira & Sepetiba Bay & $23^{\circ} 58^{\prime} \mathrm{S}$ & $44^{\circ} 2^{\prime} \mathrm{W}$ & Granite plate & Artificial \\
\hline Guaíba Island & Sepetiba Bay & $23^{\circ} 59^{\prime} \mathrm{S}$ & $44^{\circ} 7^{\prime} \mathrm{W}$ & Granite plate & Artificial \\
\hline Praia Vermelha & Guanabara Bay & $23^{\circ} 57^{\prime} \mathrm{S}$ & $43^{\circ} 9^{\prime} \mathrm{W}$ & Granite plate & Artificial \\
\hline Urca & Guanabara Bay & $23^{\circ} 57^{\prime} \mathrm{S}$ & $43^{\circ} 10^{\prime} \mathrm{W}$ & Granite plate & Artificial \\
\hline Cabo Frio Island & Cabo Frio & $23^{\circ} 0.1^{\prime} \mathrm{S}$ & $42^{\circ} 0.3^{\prime} \mathrm{W}$ & Scuba, Granite plate & Artificial \\
\hline Forno Harbor & Cabo Frio & $22^{\circ} 58^{\prime} \mathrm{S}$ & $42^{\circ} 0.8^{\prime} \mathrm{W}$ & Scuba, granite plate & Artificial \\
\hline Forno Cove & Cabo Frio & $22^{\circ} 58^{\prime} \mathrm{S}$ & $42^{\circ} 0.3^{\prime} \mathrm{W}$ & Snorkeling, granite plate & Artificial \\
\hline Itajuru Inlet & Cabo Frio & $22^{\circ} 52^{\prime} \mathrm{S}$ & $42^{\circ} 1^{\prime} \mathrm{W}$ & Granite plate & Artificial \\
\hline
\end{tabular}




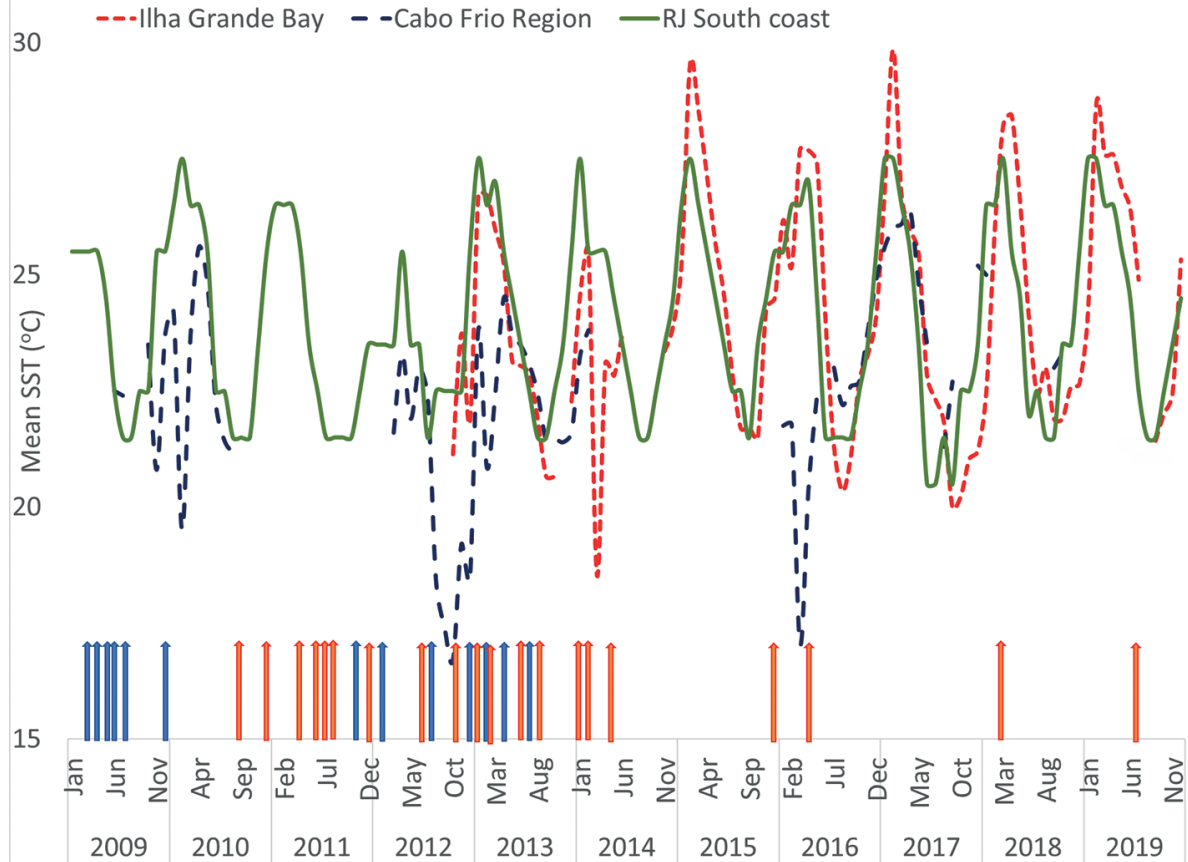

Figure 2. Mean sea surface temperatures (SST) at Ilha Grande Bay (IGB, red line), Cabo Frio (CF, blue line), and the southern coast of Rio de Janeiro State (green line) from January/2009 to December/2019. Data were obtained from Ibutton ${ }^{\oplus}$ sensors or oceanographic buoys for IGB and CF, and from satellite data for the southern coast of RJ (https://iridl.Ideo.columbia.edu/maproom/Global/Ocean_Temp). Arrows indicate the samples of Rhodosoma turcicum (red arrow) or Ciona robusta (blue arrow). Gaps in plots represent absence of data due to malfunctioning or lost sensors.

data from 2009 to 2019 indicated seasonal oscillations of SST, with higher values (circa $27^{\circ} \mathrm{C}$ ) during the austral Spring-Summer, except during the 2011-2012 season (mean $23.5^{\circ} \mathrm{C}$ ). The mean SST estimated by this method ranged from 20.5 to $27.5^{\circ} \mathrm{C}$ (mean $24^{\circ} \mathrm{C}$ ). Data from Ibutton ${ }^{\oplus}$ and buoys showed more extreme SST values (both high and low).

At llha Grande Bay, the warmest summers occurred in 2014/2015 and 2016/2017, with $63.2 \%$ of approximately 3,300 SST records from November through March $2014 / 2015$ higher than $27.1^{\circ} \mathrm{C}$. In the $2016 / 2017$ season, $84.2 \%$ of the SST records were higher than 24.1 , and $40.8 \%$ higher than $27.1^{\circ} \mathrm{C}$. SST values lower than $18.5^{\circ} \mathrm{C}$ were associated to upwelling, as occurred in February/2014 and October/2017.

The SST at Cabo Frio (Figure 2) from June/2009 to October/2018 reveals the influence of local upwelling, usually occurring from September through March. Mean SST ranged from $16.7^{\circ} \mathrm{C}$ in October $/ 2012$ to $26.4^{\circ} \mathrm{C}$ in April/2017. Two seasons draw attention: OctoberDecember/2012 and March-April/2016, with very contrasting low temperatures in Cabo Frio compared to llha Grande Bay and the remaining study sites.
Combining the SST data from all sources, we estimated the mean monthly SST values for 99 months, of which the means of 53 months (54\%) were lower than or equal to $25^{\circ} \mathrm{C}$, while those of 43 months (46\%) were higher than or equal to $25.1^{\circ} \mathrm{C}$. Those data were used to test the influence of temperature on the presence of the two species.

\section{SpeCIES OCCURRENCES}

\section{CIONA ROBUSTA Hoshino AND TOKIOKA, 1967}

Ciona individuals found along the coast of Rio de Janeiro agreed with the description of $C$. robusta by Hoshino and Tokioka (1967), as well as the revisions conducted by Sato et al. (2012) and Brunetti et al. (2015). The tunic of $C$. robusta is cartilaginous, yellowish, with the siphons having almost equal sizes at the anterior end of the body. The tunic has many tubercular protuberances, although they are sometimes restricted to the siphon or anterior regions. The body is covered by six strong longitudinal bands, from the posterior end of the body up to the siphons and red spots were observed at the margin between adjacent siphon lobes. The circular muscles of the siphons are 
not as strong as the longitudinal muscles, and do not form bands.

We analyzed the material collected between 2008 and 2013 from all regions of Rio de Janeiro State (Figure 3), and those deposited at the Zoological Collection of the Universidade do Estado do Rio de Janeiro (CZFFP), as listed in Table 2.

Ciona robusta was recorded on artificial plates in all surveyed regions (Figure 3). Ilha Grande Bay was the only site with occurrences on natural substrates, specifically at Jorge Grego Island (depth 18m), where eight individuals were found under large boulders, which are habitats resembling those simulated by experimental cages.
The lengths of the 33 individuals collected ranged from 40 to $150 \mathrm{~mm}$, with the largest specimens being those collected on natural substrates at Jorge Grego Island, at depths of $18 \mathrm{~m}$. The maximum number of individuals collected was 8 , at Jorge Grego Island (natural substrate, August/2013), and six at Guaíba Island (artificial substrate, May/2009) (Table 3).

\section{RHodosoma tURCICUM (SAVIGNY, 1816)}

The material analyzed comprised specimens collected between 2009 and 2019 at Cabo Frio and Ilha Grande Bay (Figure 3). Most individuals were encountered within protected cages, while those found on

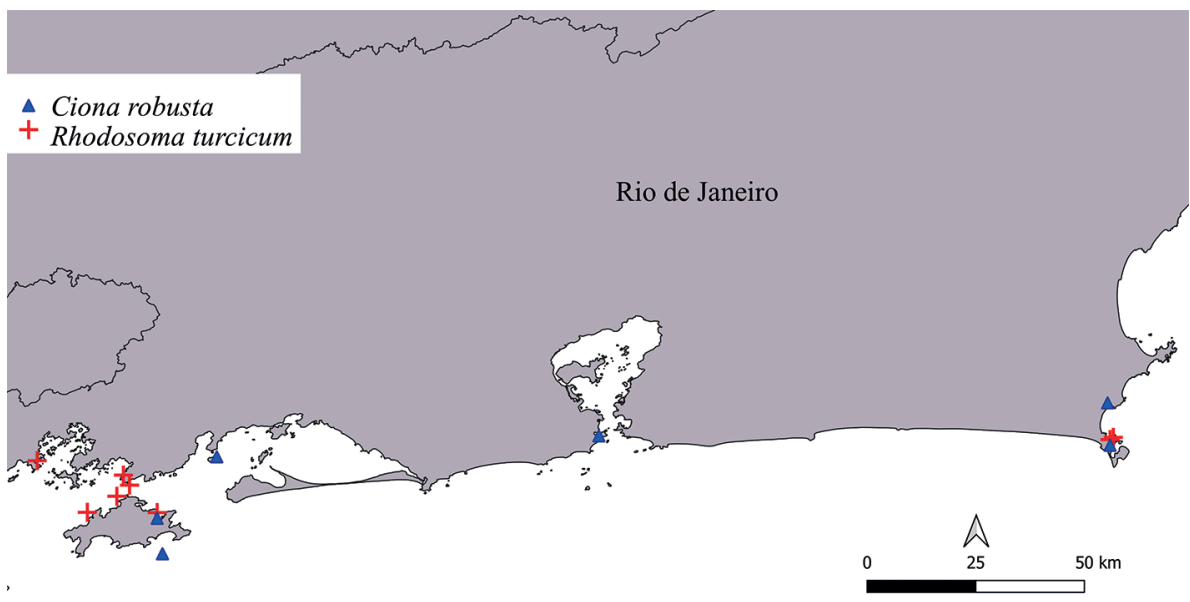

Figure 3. Occurrences of Ciona robusta (blue triangles) and Rhodosoma turcicum (red cross) in this study along the coast of Rio de Janeiro State, Brazil.

Table 2. Vouchers numbers of Ciona robusta individuals identified and deposited in the Zoological Collection of the Universidade do Estado do Rio de Janeiro (CZFFP).

\begin{tabular}{lccc}
\hline Voucher & Site & Date & Collector \\
\hline CZFFP-ASC 25 & Urca - Rio de Janeiro & $11 /$ Nov./2008 & L.F. Skinner and F.O. Marins \\
CZFFP-ASC 26 & Sepetiba Bay & May/2009 & L.F. Skinner and F.O. Marins \\
CZFFP-ASC 27 & Urca - Rio de Janeiro & $09 /$ Apr/2009 & L.F. Skinner and F.O. Marins \\
CZFFP-ASC 28 & Sepetiba bay & Mar/2009 & L.F. Skinner and F.O. Marins \\
CZFFP-ASC 31 & Forno Harbor - Arraial do Cabo & 02/Dec/2011 & L.F. Skinner and D.F. Barboza \\
CZFFP-ASC 33 & Abraão - Ilha Grande Bay & Aug/2012 & L.F. Skinner and D.F. Barboza \\
CZFFP-ASC 34 & Abraão - Ilha Grande Bay & 21/Jan/2013 & L.F. Skinner and D.F. Barboza \\
CZFFP-ASC 35 & Itajuru Inlet - Cabo Frio & Feb/2013 & L.F. Skinner and D.F. Barboza \\
CZFFP-ASC 207 & Jorge Grego Island - Ilha Grande Bay & $11 /$ Apr/2013 & L.F. Skinner \\
\hline
\end{tabular}


Table 3. Ciona robusta records for the coast of Rio de Janeiro State, Brazil, from 2009 to 2013, in the regions of Cabo Frio, Guanabara Bay, Sepetiba Bay, and Ilha Grande Bay, including sites, years and months of records, and the total number of individuals collected (** - information not available).

\begin{tabular}{lcccc}
\hline Region & Site & Year & Month & Number of individuals \\
\hline Guanabara Bay & Urca & 2008 & November & 1 \\
Sepetiba Bay & Guaíba Island & 2009 & May & 9 \\
Guanabara Bay & Urca & 2009 & June & 1 \\
Sepetiba Bay & Guaíba Island & 2009 & $* *$ & 2 \\
Guanabara Bay & Urca & 2009 & $*$ & 1 \\
Sepetiba Bay & Guaíba Island & 2010 & January & 1 \\
Cabo Frio & Forno Harbor & 2011 & December & 1 \\
Ilha Grande Bay & Abraão & 2012 & March & 1 \\
Ilha Grande Bay & Abraão & 2012 & August & 3 \\
Ilha Grande Bay & Abraão & 2013 & January & 1 \\
Cabo Frio & Itajuru Inlet & 2013 & April & 1 \\
Cabo Frio & Forno Harbor & 2013 & April & 1 \\
Illha Grande Bay & Jorge Grego Island & 2013 & August & 2 \\
Illha Grande Bay & Jorge Grego Island & 2013 & & 8
\end{tabular}

natural substrates were under boulders - and so protected from predators. The specimens are deposited in the Zoological Collection of the Universidade do Estado do Rio de Janeiro (CZFFP), as listed in Table 4.

We have identified 114 individuals obtained on 30 sampling dates. The maximum numbers of individuals collected were 13 (July/2011) and 11 (October/2010 and June/2014) found at Forno Harbor, in the Cabo Frio Region, all on artificial substrates (Table 5). Most individuals were collected during $2010(n=31)$ and $2011(n=32)$, the most intensively studied years at Cabo Frio.

The entire specimens examined (with tunic) varied from 9 to $41 \mathrm{~mm}$ in length and 3 to $23 \mathrm{~mm}$ in width. Their tunics were thick with epibionts and had greenish colorations that were lost after fixation. They were attached to the substrate by the right sides of their bodies. We found small papillae on the tunics, mainly close to the anterior region of the body. A lid in that region can be displaced by internal muscles to cover both oral and atrial siphons. It is easier to spot individuals in the field when the lid is open. Dissected individuals showed short and simple oral tentacles. Muscles were visible close to the siphons and extended onto the hinge of the lid. The dorsal tubercles were horseshoe-shaped. The pharynx was plain, without folds, and had straight stigmata and papillae sustaining the vessels. Our specimens conformed well with the descriptions provided by Van Name (1945), Kott $(1985,2005)$, and Rocha et al. (2012a, b).

\section{THE INFLUENCE OF TEMPERATURE ON SPECIES OC- CURRENCES}

Ciona robusta was recorded 15 times within the temporal window considered. Among those records, $86.7 \%$ occurred with SST between $21-25^{\circ} \mathrm{C}$, and $53.3 \%$ occurred with SST between 23.1 to $25.0^{\circ} \mathrm{C}$. Only two records (13.3\%) occurred with SST higher than $25.1^{\circ} \mathrm{C}$. The Fisher exact test was significant ( $p=0.023 ; 1$ d.f.), indicating this environmental variable as a driver of the presence of $C$. robusta.

Among the 27 records of $R$. turcicum, $11.1 \%$ corresponded to SST below $21.0^{\circ} \mathrm{C}, 59.3 \%$ between 21.1 $25.0^{\circ} \mathrm{C}, 25.9 \%$ between $25.1-29^{\circ} \mathrm{C}$ and $3.7 \%$ with SST higher than $29.1^{\circ} \mathrm{C}$. The Fisher exact test was not significant ( $p=0.1160 ; 1$ d.f.), indicating that temperature did not influence the presence of $R$. turcicum.

\section{DISCUSSION}

We detected a wider distribution range of Ciona robusta than previously recorded for the studied area (Millar, 1958; Costa, 1969; Marins et al., 2009). The only previously collected specimens that we have 
Table 4. Vouchers of Rhodosoma turcicum individuals analyzed and deposited in the Zoological Collection of the Universidade do Estado do Rio de Janeiro (CZFFP).

\begin{tabular}{lccc}
\hline Voucher & Site & Date & Collector \\
\hline CZFFP-ASC 14 & Forno Harbor - Arraial do Cabo & 23/Sep/2011 & L.F. Skinner \\
CZFFP-ASC 16 & Abraão - Ilha Grande Bay & Aug/2012 & L.F. Skinner and D.F. Barboza \\
CZFFP-ASC 19 & Forno Harbor - Arraial do Cabo & $08 /$ Apr/2013 & L.F. Skinner and D.F. Barboza \\
CZFFP-ASC 21 & Forno Beach - Arraial do Cabo & $14 /$ May/2013 & L.F. Skinner and D.F. Barboza \\
CZFFP-ASC 22 & Ponta Leste - Angra dos Reis & $27 /$ Aug/2015 & L.F. Skinner and D.F. Barboza \\
CZFFP-ASC 23 & Bananal Point - Ilha Grande Bay & $12 /$ May/2016 & L.F. Skinner and D.F. Barboza \\
CZFFP-ASC 24 & Macacos Island - Ilha Grande Bay & $12 /$ May/2016 & L.F. Skinner and D.F. Barboza \\
CZFFP-ASC346 & Piraquara de Fora - Angra dos Reis & $15 /$ Aug/2019 & L.F. Skinner \\
\hline
\end{tabular}

Table 5. List of Rhodosoma turcicum records for the coast of Rio de Janeiro State, Brazil, from 2010 to 2019, in the regions near Cabo Frio region and Ilha Grande Bay, including sites, years and months of records, and the total number of individuals collected ${ }^{* *}$ - information not available).

\begin{tabular}{|c|c|c|c|c|}
\hline Region & Site & Year & Month & Number of individuals \\
\hline Cabo Frio & Forno Harbor & 2010 & January & 9 \\
\hline Cabo Frio & Forno Harbor & 2010 & February & 1 \\
\hline Cabo Frio & Forno Harbor & 2010 & May & 3 \\
\hline Cabo Frio & Forno Harbor & 2010 & September & 6 \\
\hline Cabo Frio & Forno Harbor & 2010 & October & 11 \\
\hline Cabo Frio & Forno Harbor & 2010 & $* *$ & 1 \\
\hline Cabo Frio & Forno Harbor & 2011 & July & 13 \\
\hline Cabo Frio & Forno Harbor & 2011 & August & 4 \\
\hline Cabo Frio & Forno cove & 2011 & August & 3 \\
\hline Cabo Frio & Forno Harbor & 2011 & September & 6 \\
\hline Cabo Frio & Forno Harbor & 2011 & $* *$ & 6 \\
\hline Cabo Frio & Forno Harbor & 2012 & February & 1 \\
\hline Ilha Grande Bay & Abraão & 2012 & August & 7 \\
\hline Cabo Frio & Forno Harbor & 2012 & December & 1 \\
\hline Cabo Frio & Forno Harbor & 2013 & January & 1 \\
\hline Cabo Frio & Forno Harbor & 2013 & February & 1 \\
\hline Cabo Frio & Forno Harbor & 2013 & April & 4 \\
\hline Cabo Frio & Forno cove & 2013 & May & 2 \\
\hline Cabo Frio & Forno Harbor & 2013 & August & 1 \\
\hline Cabo Frio & Forno Harbor & 2014 & February & 8 \\
\hline Ilha Grande Bay & Longa Island & 2014 & June & 11 \\
\hline Ilha Grande Bay & Ponta Leste & 2015 & August & 1 \\
\hline Ilha Grande Bay & Ponta Leste & 2016 & January & 1 \\
\hline Ilha Grande Bay & Bananal point & 2016 & May & 1 \\
\hline Ilha Grande Bay & Macacos Island & 2016 & May & 1 \\
\hline Ilha Grande Bay & Piraquara de Fora & 2018 & April & 3 \\
\hline Ilha Grande Bay & Piraquara de Fora & 2019 & August & 5 \\
\hline Cabo Frio & Forno Harbor & $* *$ & $* *$ & 1 \\
\hline Cabo Frio & Forno Harbor & $* *$ & $* *$ & 1 \\
\hline
\end{tabular}


examined were those of Marins et al. (2009) but considering the confirmation of recent specimens in Rio de Janeiro as $C$. robusta, and the widespread occurrence of that species in the Southern Hemisphere, we believe that earlier records in Brazil belongs to this species and not to $C$. intestinalis, and should be corrected (Sato et al., 2012; Brunetti et al., 2015).

Ciona robusta was detected at Ilha Grande Bay during an early phase of our monitoring, which appears to be related to intermediate water temperatures. This is because we have not recorded C. robusta at Ilha Grande Bay since 2013, when higher than normal SSTs (sometimes reaching $33^{\circ} \mathrm{C}$ ) have occurred (Skinner, 2018a, b). The temperature tolerance range of $C$. robusta was experimentally tested by Kim et al. (2019) and showed that egg development and larval settlement is greater at temperatures between 16 and $20^{\circ} \mathrm{C}$. Caputi et al. (2019) indicated that C. robusta density is associated with SST, with low densities from May to September, the time period with the highest SSTs (24.3 to $27.5^{\circ} \mathrm{C}$ ). Rocha et al. (2017) reported that a temperature range of 20 to $25^{\circ} \mathrm{C}$ is best for egg, larval, and adult development and recruitment. Our data, in a multiyear comparison, indicate predominance of $C$. robusta records during periods with mean SST lower than $25.0^{\circ} \mathrm{C}$, corroborating the findings of Caputi et al. (2015).

Previous records of $C$. robusta in Brazil were made from Cabo Frio (RJ) to São Paulo (Millar, 1958; Costa, 1969; Marins et al., 2009; Rocha and Bonnet, 2009; Dias et al., 2013), covering the Warm Temperate Southwestern Atlantic (WTSA) Marine Ecoregion (Spalding et al., 2007; Bouchemousse et al., 2016), influenced by upwelling events, mainly during spring and summer months. SST values in the Cabo Frio region may drop below $20^{\circ} \mathrm{C}$ (Skinner et al., 2011; Batista et al., 2017; Boltovskoy and Valentin, 2018). Extreme high SST, however, can prevent reproduction or even kill adults growing in shallow waters in the region (Caputi et al., 2015; Rocha et al., 2017), which would contribute to the irregular historical records of the species along the coast of Rio de Janeiro. Those records, and successful introductions of $C$. robusta along the southeastern coast of Brazil, could be related to El Niño/La Niña events that increase or reduce SSTs in the Atlantic Ocean. The 2007-2008-2009, 2010-2011-2012 seasons, when some of our records were made, were characterized by strong to neutral La Niña seasons with negative average anomalies (NOAA, 2019). Data from sensors and buoys confirmed lower SSTs during those years. Records of $C$. robusta at llha Grande Bay ceased after the strong El Niño events of 2014-2015-2016, when SST reached $33^{\circ} \mathrm{C}$ (at depths down to $10 \mathrm{~m}$ ) during summer months. There is no evidence of the presence of C. robusta at Cabo Frio in summer 2016 when SST presumably reached favorable conditions for the species $\left(17\right.$ to $22^{\circ} \mathrm{C}$ ).

Shenkar et al. (2018) argues that C. robusta is acclimated to both temperate and tropical areas, matching the environmental conditions of the southwestern Brazilian Coast. Bouchemousse et al. (2016) published the global distribution of $C$. robusta, which included the South Brazilian coast (after introductions in the mid-20 $0^{\text {th }}$ century). According to the SST patterns recorded along the coast of Rio de Janeiro State, the most suitable region for the continuous occupation of $C$. robusta is the region near Cabo Frio, where SST usually range from 12.5 to $29.0^{\circ} \mathrm{C}$ (Skinner et al., 2011; Batista et al., 2017).

Ciona robusta is an invasive species, often fouling substrates in aquaculture farms (Clancey and Hinton, 2003; Daley and Scavia, 2008; Ramsay et al., 2008; Fofonoff et al., 2019; Global Invasive Species Database, 2019; Kim et al., 2019), and their establishment in bivalve farms along the southern Brazilian coast is a threat to that industry. The socking or pearl net methods (Baylon, 1990) usually employed by farmers help to prevent predation events but could favor $C$. robusta recruitment, growth, and spread. Some fouling prevention procedures can also deter $C$. robusta development, but certain suspended structures can serve as refuge for the species.

Rhodosoma turcicum was first recorded at Cabo Frio from 2009 to 2012 (Skinner et al., 2013), at Sepetiba Bay in 2012, and at Ilha Grande Bay from 2012 to 2019. There are other reports about this species on northeast Brazil, at Bahia and Ceará, but those records remain unpublished on thesis and reports. The species was recorded on both artificial and natural substrates at llha Grande and Cabo Frio. The first records of R. turcicum at llha Grande Bay were on eastern sites (2012); records from the most western site refer to 2018 and 2019 samples. Thus, our records and those from Granthom-Costa et al. (2016) indicate that this species is spreading in Rio de Janeiro 
State, mainly at Cabo Frio and Ilha Grande Bay. The alternative hypothesis of variable sampling effort is not supported because even at sites where sampling was performed along an extensive period, from early 2012 to 2019, records of this species were scarce.

SST lower than $25^{\circ} \mathrm{C}$ and up to $31^{\circ} \mathrm{C}$ do not appear to be limiting for R. turcicum, as our surveys both at the warmest (Piraquara de Fora) and at the coldest sites (Arraial do Cabo Bay) recorded the species. Based on the global distribution of $R$. turcicum, its temperature range is from 20 to $30^{\circ} \mathrm{C}$, with most records within the $25-30^{\circ} \mathrm{C}$ range (OBIS, 2019). Shenkar and Loya (2009) suggested $22^{\circ} \mathrm{C}$ as the lower limit for this species. It is a tropical species recorded from the Caribbean, Mediterranean, and the Red Sea, and is tolerant to high temperatures.

Some aspects are relevant to the detection of $C$. robusta and $R$. turcicum. The tunics of both species are reasonably soft as compared to other solitary ascidians recorded on natural or artificial substrates in Rio de Janeiro State, such as Phallusia nigra Savigny, 1816, Styela plicata (Lesueur, 1823), Herdmania pallida (Heller, 1878), and Microcosmus exasperatus Heller, 1878 (Marins et al., 2010; Granthom-Costa et al., 2016; Skinner et al., 2016). Those differences in tunic thicknesses and chemical/physical defenses will be determinant for ascidian palatability to predators such as fish (Monniot et al., 1991; Tarallo et al., 2016). The recently described Pyura beta Skinner, Rocha \& Counts (2019), recognized as introduced into the SW Atlantic, also have a hard tunic that reduces predation. The effects of predator control on Ciona spp. (Marins et al., 2009; Dumont et al., 2011) and other ascidian species are frequently cited in the literature (Epelbaum et al., 2009; Freestone et al., 2011).

Another common and important factor potentially affecting species introduction and spreading is the proximity of harbors and marinas. The region from Cabo Frio to São Sebastião in the SW Atlantic experiences intense marine ship traffic, potentially connecting those coastal areas to several tropical and subtropical biogeographical realms throughout the world (Seebens et al., 2013; Brasil, 2019; Sardain et al., 2019). Transoceanic cruise ships, passenger vessels, and many fishing boats and yachts cross those waters daily, and could locally spread introduced species (Zabin et al., 2014; Skinner et al., 2016; Kauano et al., 2017).
It will be necessary to establish continuous monitoring and experimental procedures considering predator exclusion near Cabo Frio to test the hypothesis that the continuous records of $C$. robusta there, in contrast to the discontinuous sightings at Ilha Grande and other regions, can be attributed to the lower SST related to upwelling. It would also represent a good opportunity to test the effects of upwelling strength and other climatic and oceanographic variables such as wind intensity and direction on $C$. robusta establishment.

\section{AUTHOR CONTRIBUTIONS}

D.F.B.: Conceptualization; Investigation; Methodology; Formal analysis; Writing - original draft; Writing review \& editing.

L.F.S.: Conceptualization; Investigation; Methodology; Funding acquisition; Project administration; Supervision; Writing - original draft; Writing review \& editing.

\section{ACKNOWLEDGMENTS}

Authors would like to thank Dr. Helena Passeri Lavrado (UFRJ) for the suggestions on statistical analysis and the two referees who suggested many improvements in this manuscript. This work was supported by the Fundação de Amparo à Pesquisa do Estado do Rio de Janeiro - FAPERJ (Proc. \#E-26/11.454/2011). The authors are grateful for the scholarship awarded to DFB by the Coordenação de Aperfeiçoamento de Pessoal de Nível Superior - Brasil (CAPES) - Finance Code 001, the logistic support provided by CEADS-UERJ.

\section{REFERENCES}

BNDO (Base Nacional de Dados Oceanográficos). 2020. Centro de Hidrografia da Marinha - Dados PNBOIA [online]. Brasil: Marinha do Brasil. Available at: https://www.marinha.mil.br/chm/ dados-do-goos-brasil/pnboia-mapa [Accessed 8 May 2020].

BATISTA, D., GONÇALVES, J. E. A., MESSANO, H. F., ALTVATER, L., CANDELLA, R., ELIAS, L. M. C., MESSANO, L. V. R., APOLINÁRIO, M. \& COUTINHO, R. 2017. Distribution of the invasive orange cup coral Tubastraea coccinea Lesson, 1829 in an upwelling area in the South Atlantic Ocean fifteen years after its first record. Aquatic Invasions, 12(1), 23-32, DOI: https://doi.org/10.3391/ai.2017.12.1.03

BAYLON, C. B. 1990. Culture of bivalve molluscs. Selected papers on mollusc culture [online]. Bangkok: NDP/FAO Regional Seafarming Development and Demonstration Project (RAS/90/002). Available at: http:// www.fao.org/3/ab737e/AB737E02.htm\#ch2 [Accessed 10 May 2020]. 
BLACKBURN, T. M., BELLARD, C. \& RICCIARDI, A. 2019. Alien versus native species as driver of recent extinction. Frontiers in Ecology and the Environment, 17(4), 203-207, DOI: https:// doi.org/10.1002/fee. 2020

BOLTOVSKOY, D. \& VALENTIN, J. L. 2018. Overview of the history of biological oceanography in the southwestern Atlantic, with emphasis on plankton. In: HOFFMEYER, M. S., SABATINI, M. E., BRANDINI, F. P., CALLIARI, D. L. \& SANTINELLI, N. H. Plankton ecology of the southwestern Atlantic [ebook]. Cham: Springer, pp. 3-34. Available at: https://link.springer. com/book/10.1007\%2F978-3-319-77869-3\#about [Accessed 15 Apr. 2020].

BOLTOVSKOY, D., SYLVESTER, F. \& PAOLUCCI, E. M. 2018. Invasive species denialism: sorting out facts, beliefs, and definitions. Ecology and evolution, 8(22), 11190-11198, DOI: https://doi. org/10.1002/ece3.4588

BOUCHEMOUSSE, S., BISHOP, J. D. \& VIARD, F. 2016. Contrasting global genetic patterns in two biologically similar, widespread and invasive Ciona species (Tunicata, Ascidiacea). Scientific Reports, 6, 24875, DOI: https://doi.org/10.1038/ srep24875

BRASIL. Ministério da Infraestrutura. 2019. Plano Mestre - Complexo portuário de Forno/RJ - Sumário Executivo [online]. Rio de Janeiro: Ministério da Infraestrutura. Available at: http:// antigo.infraestrutura.gov.br/images/planos-mestres-sumarios-executivos/FNO-Sum_Exec_simples.pdf [Accessed 15 Dec. 2019].

BRUNETTI, R., GISSI, C., PENNATI, R., CAICCI, F., GASPARINI, F. \& MANNI, L. 2015. Morphological evidence that the molecularly determined Ciona intestinalis type $A$ and type $B$ are different species: Ciona robusta and Ciona intestinalis. Journal of Zoological Systematics and Evolutionary Research, 53(3), 186-193, DOI: https://doi.org/10.1111/jzs.12101

CAPUTI, L., TOSCANO, F., ARIENZO, M., FERRARA, L., PROCACCINI, G. \& SORDINO, P. 2019. Temporal correlation of population composition and environmental variables in the marine invader Ciona robusta. Marine Ecology, 40(2), e12543, DOI: https://doi.org/10.1111/maec.12543

CAPUTI, L., CROCETTA, F., TOSCANO, F., SORDINO, P. \& CIRINO, P. 2015. Long-term demographic and reproductive trends in Ciona intestinalis sp. A. Marine Ecology, 36(1), 118-128, DOI: https://doi.org/10.1111/maec.12125

CARLTON, J. T. \& ELDREDGE, L. G. 2009. Marine bioinvasions of Hawai'i: the introduced and cryptogenic marine and estuarine animals and plants of the Hawaiian archipelago. Bishop Museum Bulletin in Cultural and Environmental Studies, 4, 1-203.

CLANCEY, L. \& HINTON, R. 2003. Distribution of the tunicate, Ciona intestinalis. Nova Scotia: Nova Scotia Department Agriculture and Fisheries.

COE, H. H., CARVALHO, C. N., SOUZA, L. O. \& SOARES, A. 2007. Peculiaridades ecológicas da região de Cabo Frio. Revista Tamoios, 3(2), 1-20.

COLARUSSO, P., NELSON, E., AYVAZIAN, S., CARMAN, M. R., CHINTALA, M., GRABBERT, S. \& GRUNDEN, D. 2016. Quantifying the ecological impact of invasive tunicates to shallow coastal water systems. Management of Biological Invasions, 7(1), 33-42, DOI: http://dx.doi.org/10.3391/ mbi.2016.7.1.05
COMAP (Companhia Municipal de Administração Portuária). 2008. Atualização do plano de desenvolvimento ezoneamento do Porto do Forno - 2008-2012 [online]. Arraial do Cabo: COMAP. Available at: http://www.transportes.gov.br/images/SNP/planejamento_portuario/pdz/pdz09.pdf[Accessed 15 Dec. 2019].

COSTA, H. R. 1969. Notas sobre os Ascidiacea brasileiros. IV. Ordem Phlebobranchia (Lahille, 1887). Atas da Sociedade de Biologia do Rio de Janeiro, 12(5-6), 289-292.

CREED, J. C., FENNER, D., SAMMARCO, P., CAIRNS, S., CAPEL, K., JUNQUEIRA, A. O. R., CRUZ, I., MIRANDA, R. J., CARLOS JUNIOR, L., MANTELATTO, M. C. \& OIGMAN-PSZCZOL, S. 2017. The invasion of the azooxanthellate coral Tubastraea (Scleractinia: Dendrophylliidae) throughout the world: history, pathways and vectors. Biological Invasions, 19(1), 283-305, DOI: https://doi.org/10.1007/s10530-016-1279-y

CREED, J. C., PIRES, D. O. \& FIGUEIREDO, M. A. O. 2007. Biodiversidade marinha da baía da llha Grande. Brasília: Ministério do Meio Ambiente (MMA)/Secretaria de Biodiversidade e Florestas (SBF).

CROOKS, J. A., CHANG, A. L. \& RUIZ, G. M. 2011. Aquatic pollution increases the relative success of invasive species. Biological Invasions, 13(1), 165-176, DOI: https://doi.org/10.1007/ s10530-010-9799-3

DALEY, B. A. \& SCAVIA, D. 2008. An integrated assessment of the continued spread and potential impacts of the colonial ascidian, Didemnum sp. A, in US waters. NOAA Technical Memorandum NOS NCCOS, 78, 1-70.

DARBYSON, E. A., HANSON, J. M., LOCKE, A. \& WILLISON, J. H. M. 2009. Settlement and potential for transport of clubbed tunicate (Styela clava) on boat hulls. Aquatic Invasions, 4(1), 95-103.

DIAS, G. M., ROCHA, R. M., LOTUFO, T. M. C. \& KREMER, L. P. 2013. Fifty years of ascidian biodiversity research in São Sebastião, Brazil. Journal of the Marine Biological Association of the United Kingdom, 93(1), 273-282, DOI: https://doi.org/10.1017/ S002531541200063X

DIAS, P. J., CARMAN, M. R. \& BULLARD, S. G. 2019. All for one and one for all: research from the 6th International Invasive Sea Squirt Conference and the 10th International Conference on Marine Bioinvasions. Management of Biological Invasions, 10(4), 597601, DOI: https://doi.org/10.3391/mbi.2019.10.4.01

DUMONT, C. P., GAYMER, C. F. \& THIEL, M. 2011. Predation contributes to invasion resistance of benthic communities against the non-indigenous tunicate Ciona intestinalis. Biological Invasions, 13(9), 2023-2034, DOI: https://doi.org/10.1007/ s10530-011-0018-7

EPELBAUM, A., PEARCE, C. M., BARKER, D. J., PAULSON, A. \& THERRIAULT, T. W. 2009. Susceptibility of non-indigenous ascidian species in British Columbia (Canada) to invertebrate predation. Marine Biology, 156(6), 1311-1320, DOI: https://doi.org/10.1007/s00227-009-1172-7

FOFONOFF, P. W., RUIZ, G. M., STEVES, B., HINES, A. H. \& CARLTON, J. T. 2019. National exotic marine and estuarine species information system. Nemesis [online]. Available at: http://invasions.si.edu/nemesis/ [Accessed 13 Dec. 2019].

FOWLER, A. E., BLAKESLEE A. M. H., BORTOLUS A., DIAS, J., TEPOLT, C. K. \& SCHWINDT, E. 2020 Current research, pressing issues, and lingering questions in marine invasion science: lessons from the Tenth International Conference on Marine Bioinvasions (ICMB-X). Aquatic Invasions, 15(1), 1-10, DOI: https://doi.org/10.3391/ai.2020.15.1.01 
FREESTONE, A. L., OSMAN, R. W., RUIZ, G. M. \& TORCHIN, M. E. 2011. Stronger predation in the tropics shapes species richness patterns in marine communities. Ecology, 92(4), 983993.

GISD (Global Invasive Species Database). 2019. Species profile: Ciona intestinalis [online]. Abu Dhabi: GISD. Available at: http://www.iucngisd.org/gisd/speciesname/ Ciona+intestinalis [Accessed 10 May 2020].

GRANOT, I., SHENKAR, N. \& BELMAKER, J. 2017. Habitat niche breadth predicts invasiveness in solitary ascidians. Ecology and Evolution, 7(19), 7838-7847, DOI: https://doi. org/10.1002/ece 3.3351

GRANTHOM-COSTA, L. V., FERREIRA, C. G. W. \& DIAS, G. M. 2016. Biodiversity of ascidians in a heterogeneous bay from southeastern Brazil. Management of Biological Invasions, 7(1), 5-12, DOI: https://doi.org/10.3391/mbi.2016.7.1.02

GREY, E. K. 2010. Effects of large enemies on success of exotic species in marine fouling communities of Washington, USA. Marine Ecology Progress Series, 411, 89-100, DOI: https://doi. org/10.3354/meps08645

HOSHINO, Z. \& TOKIOKA, T. 1967. An unusually robust Ciona from the northeastern coast of Honsyu Island, Japan. Publications of the Seto Marine Biological Laboratory, 15(4), 275290.

IGNACIO, B. L., JULIO, L. M., JUNQUEIRA, A. O. R. \& FERREIRA-SILVA, M. A. G. 2010. Bioinvasion in a Brazilian bay: filling gaps in the knowledge of southwestern Atlantic biota. PLoS ONE, 5(9), e13065, DOI: https://doi.org/10.1371/journal. pone. 0013065

INEA (Instituto Estadual do Ambiente). 2015. Diagnóstico do setor costeiro da Baía da llha Grande: Subsídios à elaboração do zoneamento ecológico-econômico costeiro - Volumel [online]. Rio de Janeiro: INEA. Available at: http://www.inea. rj.gov.br/cs/groups/public/documents/document/zwew/ mdcz/ edisp/inea0073532.pdf [Acessed 12 Nov. 2019].

JUNQUEIRA, A. O. R. 2013. Guilty or innocent? The need to improve the assessment of impacts caused by non-native species. Aquatic Conservation: Marine and Freshwater Ecosystems, 23(5), 641-645, DOI: https://doi.org/10.1002/aqc.2392

KAKKONEN, J. E., WORSFOLD, T. M., ASHELBY, C. W., TAYLOR, A. \& BEATON, K. 2019. The value of regular monitoring and diverse sampling techniques to assess aquatic non-native species: a case study from Orkney. Management of Biological Invasions, 10(1), 46-79, DOl: https://doi.org/10.3391/mbi.2019.10.1.04

KAUANO, R. V., ROPER, J. J. \& ROCHA, R. M. 2017. Small boats as vectors of marine invasion: experimental test of velocity and desiccation as limits. Marine Biology, 164, 27, DOI: https://doi.org/10.1007/s00227-016-3057-x

KIM, M. K., KIM, D. H., PARK, J. U., KIM, D. H., YOON, T. J., KIM, D. G., LEE, Y. \& SHIN, S. 2019. Effects of temperature and salinity on the egg development and larval settlement of Ciona robusta (Ascidiacea, Phlebobranchia, Cionidae). Ocean Science Journal, 54, 97-106, DOI: https://doi.org/10.1007/s12601-0180056-5

KOTT, P. 1985. The Australian Ascidiacea part I: Phlebobranchia and Stolidobranchia. Memoirs of the Queensland Museum, 23, 1-440.

KOTT, P. 2005. Catalogue of Tunicata in Australian waters. Canberra: Australian Biological Resources Study.
KREMER, L. P. \& ROCHA, R. M. 2011. The role of Didemnum perlucidum F. Monniot, 1983 (Tunicata, Ascidiacea) in a marine fouling community. Aquatic Invasions, 6(4), 441-449, DOI: https://doi.org/10.3391/ai.2011.6.4.09

LAMBERT, G. 2005. Ecology and natural history of the protochordates. Canadian Journal of Zoology, 83(1), 34-50.

MARINS, F. O., OLIVEIRA, C. S., MACIEL, N. M. V. \& SKINNER, L. F. 2009. Reinclusion of Ciona intestinalis (Ascidiacea: Cionidae) in Brazil - a methodological view. Marine Biodiversity Records, 2, e112.

MARINS, F. O., NOVAES, R. L. M., ROCHA, R. M. \& JUNQUEIRA, A. O. R. 2010. Non indigenous ascidians in port and natural environments in a tropical Brazilian bay. Zoologia (Curitiba), 27(2), 213-221, DOI: https://doi.org/10.1590/S198446702010000200009

MCKINDSEY, C. W., LANDRY, T., O'BEIRN, F. X. \& DAVIES, I. M. 2007. Bivalve aquaculture and exotic species: a review of ecological considerations and management issues. Journal of Shellfish Research, 26(2), 281-295.

MILLAR, R. H. 1958. Some ascidians from Brazil. Annals and Magazine of Natural History, 1(8), 497-514.

MILLAR, R. H. 1971. The biology of ascidians. Advances in Marine Biology, 9, 1-100.

MONNIOT, C., MONNIOT, F. \& LABOUTE, P. 1991. Coral reef ascidians of New Caledonia (No. 30). Paris: Editions de I'ORSTOM.

NOAA. National Weather Service. Climate Prediction Center. 2019. El Niño/Southern oscillation (ENSO) diagnostic discussion [online]. Maryland: NOAA. Available at: https://origin. cpc.ncep.noaa.gov/products/analysis_monitoring/ [Accessed 5 Dec. 2019].

OBIS (Ocean Biodiversity Information System). 2019. Rhodosoma turcicum (Savigny, 1815) [online]. New Jersey: OBIS. Available at: https://obis.org/taxon/103749 [Accessed 20 Nov. 2019].

O'BRIEN, C. E., JOHNSTON, M. W. \& KERSTETTER, D. W. 2017. Ports and pests: assessing the threat of aquatic invasive species introduced by maritime shipping activity in Cuba. Marine Pollution Bulletin, 125(1-2), 92-102, DOl: https://doi. org/10.1016/j.marpolbul.2017.07.071

ORICCHIO, F., MARQUES, A., HAJDU, E., PITOMBO, F., AZEVEDO, F., PASSOS, F., VIEIRA, L., STAMPAR, S., ROCHA, R. \& DIAS, G., 2019. Exotic species dominate marinas between the two most populated regions in the southwestern Atlantic Ocean. Marine Pollution Bulletin, 146, 884-892.

PAETZOLD, S. C., GIBERSON, D. J., HILL, J., DAVIDSON, J. D. P. \& DAVIDSON, J. 2012. Effect of colonial tunicate presence on Ciona intestinalis recruitment within a mussel farming environment. Management of Biological Invasions, 3(1), 15-23, DOI: https://doi.org/10.3391/mbi.2012.3.1.02

PERKOL-FINKEL, S., ZILMAN, G., SELLA, I., MILOH, T. \& BENAYA$\mathrm{HU}$, Y. (2006). Floating and fixed artificial habitats: effects of substratum motion on benthic communities in a coral reef environment. Marine Ecology Progress Series, 317, 9-20.

RAMSAY, A., DAVIDSON, J., LANDRY, T. \& STRYHN, H. 2008. The effect of mussel seed density on tunicate settlement and growth for the cultured mussel, Mytilus edulis. Aquaculture, 275(1-4), 194-200, DOI: https://doi.org/10.1016/j. aquaculture.2008.01.024

ROCHA, R. M. 1995. Abundance and distribution of sessile invertebrates under intertidal boulders (São Paulo, Brazil). Boletim do Instituto Oceanográfico, 43(1), 71-88. 
ROCHA, R. M. \& COSTA, L. V. G. 2005. Ascidians (Urochordata: Ascidiacea) from Arraial do Cabo, Rio de Janeiro, Brazil. Iheringia. Sries Zoologia, 95(1), 57-64, DOI: https://doi. org/10.1590/S0073-47212005000100009

ROCHA, R. M., BONNET, N. Y. K., BAPTISTA, M. S. \& BELTRAMIN, F. S. 2012. Introduced and native Phlebobranch and Stolidobranch solitary ascidians (Tunicata: Ascidiacea) around Salvador, Bahia, Brazil. Zoologia (Curitiba), 29(1), 39-53, DOI: https://doi.org/10.1590/S1984-46702012000100005

ROCHA, R. M., ZANATA, T. B. \& MORENO, T. R. 2012. Keys for the identification of families and genera of Atlantic shallow water ascidians. Biota Neotropica, 12(1), 269-303, DOI: https:// doi.org/10.1590/S1676-06032012000100022

ROCHA, R. M., CASTELLANO, G. C. \& FREIRE, C. A. 2017. Physiological tolerance as a tool to support invasion risk assessment of tropical ascidians. Marine Ecology Progress Series, 577, 105-119, DOI: https://doi.org/10.3354/meps12225

ROCHA, R. M., KREMER, L. P., BAPTISTA, M. S. \& METRI, R. 2009. Bivalve cultures provide habitat for exotic tunicates in southern Brazil. Aquatic invasions, 4(1), 195-205, DOI: https:// doi.org/10.3391/ai.2009.4.1.20

ROCHA, R. M. \& BONNET, N. Y. K. 2009. Ascídias (Tunicata, Ascidiacea) introduzidas no Arquipélago de Alcatrazes, São Paulo. Iheringia. Series Zoologie, 99(1), 27-35.

ROTH, F., STUHLDREIER, I., SÁNCHEZ-NOGUERA, C., CARVALHO, S. \& WILD, C. 2017. Simulated overfishing and natural eutrophication promote the relative success of a non-indigenous ascidian in coral reefs at the Pacific coast of Costa Rica. Aquatic Invasions, 12, 435-446, DOI: https://doi. org/10.3391/ai.2017.12.4.02

SARDAIN, A., SARDAIN, E. \& LEUNG, B. 2019. Global forecasts of shipping traffic and biological invasions to 2050. Nature Sustainability, 2, 274-282.

SAVIGNY, J., 1816. Mémoires sur les Animaux sans vertèbres. Paris.

SATO, A., SATOH, N. \& BISHOP, J. D. D. 2012. Field identification of 'types' $A$ and $B$ of the ascidian Ciona intestinalis in a region of sympatry. Marine Biology, 159(7), 1611-1619, DOI: https://doi.org/10.1007/s00227-012-1898-5

SEEBENS, H., GASTNER, M. T. \& BLASIUS, B. 2013. The risk of marine bioinvasion caused by global shipping. Ecology Letters, 16(6), 782-790, DOI: https://doi.org/10.1111/ele.12111

SHENKAR, N. \& LOYA, Y. (2009). Non-indigenous ascidians (Chordata: Tunicata) along the Mediterranean coast of Israel. Marine Biodiversity Records, 2, e166, DOI: https://doi. org/10.1017/S1755267209990753

SHENKAR, N., SHMUEL, Y. \& HUCHON, D. 2018. The invasive ascidian Ciona robusta recorded from a Red Sea marina. Marine Biodiversity, 48(4), 2211-2214, DOI: https://doi.org/10.1007/ s12526-017-0699-y

SILVA, A. C. P., SPATA, A. O. \& LIMA, M. S. C. 2018. Gestão ambiental integrada na Região Metropolitana do Rio de Janeiro: a avaliação de impactos cumulativos e sinérgicos entre cidades milionárias - o exemplo da baia de Sepetiba (RJ). Confins, 38, DOI: https://doi.org/10.4000/confins. 16960

SKINNER, L. F. 2018a. Sea surface temperature measured since 2012 for Ponta leste, Angra dos Reis, Rio de Janeiro, Brazil. Researchgate [online]. Available at: https://www.researchgate.net/project/Conhecendo-e-Divulgando-a-Biodiversidade-Marinha-da-Baia-da-Ilha-Grande [Accessed 10 Oct. 2019], DOI: https://doi.org/10.13140/RG.2.2.19686.27205
SKINNER, L. F. 2018b. Sea surface temperature measured since 2012 for Dois Rios cove, Ilha Grande, Rio de Janeiro, Brazil. Researchgate [online]. Available at: https://www.researchgate.net/project/Conhecendo-e-Divulgando-a-Biodiversidade-Marinha-da-Baia-da-llha-Grande [Accessed 10 Oct. 2019], DOI: https://doi.org/10.13140/RG.2.2.12975.38560

SKINNER, L. F., BARBOZA, D. F. \& ROCHA, R. M. 2016. Rapid assessment survey of introduced ascidians in a region with many marinas in the southwest Atlantic Ocean, Brazil. Management of Biological Invasions, 7(1), 13-20, DOI: http://dx.doi. org/10.3391/mbi.2016.7.1.03

SKINNER, L. F., MACHARET, H. K. L. \& COUTINHO, R. 2011. Influence of upwelling and tropical environments on the breeding development of the intertidal barnacle Tetraclita stalactifera (Lamarck, 1818). Brazilian Journal of Oceanography, 59(4), 349-356, DOI: https://doi.org/10.1590/S1679-87592011000400005

SKINNER, L. F., ROCHA, R. M. \& COUNTS, B. K. 2019. Pyura gangelion and Pyura beta Sp. Nov. (Ascidiacea: Pyuridae): An exotic and a new tunicate from the west Atlantic. Zootaxa 4545 (2): 264. doi:10.11646/zootaxa.4545.2.6.

SKINNER, L. F., OLIVEIRA, G. C. M., BARBOZA, D. F., TENÓRIO, A. A. \& SOARES, D. C. 2013. First record of the Ascidiacea Rhodosoma turcicum in the south-west Atlantic Ocean. Marine Biodiversity Records, 6, e37, DOI: https://doi. org/10.1017/S1755267213000092

SPALDING, M. D., FOX, H. E., ALLEN, G. R., DAVIDSON, N., FERDAÑA, Z. A., FINLAYSON, M., HALPERN, B. S., JORGE, M. A., LOMBANA, A., LOURIE, S. A., MARTIN, K. D., MCMANUS, E., MOLNAR, J., RECCHIA, C. A. \& ROBERTSON, J. 2007. Marine ecoregions of the world: a bioregionalization of coastal and shelf areas. BioScience, 57(7), 573-583, DOI: https://doi. org/10.1641/B570707

TARALLO, A., YAGI, M., OIKAWA, S., AGNISOLA, C. \& D'ONOFRIO, G. 2016. Comparative morphophysiological analysis between Ciona robusta and Ciona savignyi. Journal of Experimental Marine Biology and Ecology, 485, 83-87, DOI: https:// doi.org/10.1016/j.jembe.2016.09.001

UNDERWOOD, A. J. 1997. Experiments in ecology: their logical design and interpretation using analysis of variance. Cambridge: Cambridge University Press, DOI: https://doi. org/10.1017/CBO9780511806407

VALENTIN, J. L. 2001. The Cabo Frio upwelling system, Brazil. In: SEELIGER, U. \& KJERFVE, B. (eds.). Coastal marine ecosystems of Latin America. Berlin: Springer. pp. 97-105.

VAN NAME, W. G. 1945. North and South American ascidians. Bulletin of the American Museum of Natural History, 84, 1-462.

VIEIRA, E. A., DUARTE, L. F. L. \& DIAS, G. M. 2012. How the timing of predation affects composition and diversity of species in a marine sessile community?. Journal of Experimental Marine Biology and Ecology, 412, 126-133, DOI: https://doi. org/10.1016/j.jembe.2011.11.011

ZABIN, C. J., ASHTON, G. V., BROWN, C. W., DAVIDSON, I. C., SYTSMA, M. D. \& RUIZ, G. M. 2014. Small boats provide connectivity for nonindigenous marine species between a highly invaded international port and nearby coastal harbors. Management of Biological Invasions, 5(2), 97-112, DOI: https:// doi.org/10.3391/mbi.2014.5.2.03

ZHAN, A., BRISKI, E., BOCK, D. G., GHABOOLI, S. \& MACISAAC, H. J. 2015. Ascidians as models for studying invasion success. Marine Biology, 162(12), 2449-2470, DOI: https://doi. org/10.1007/s00227-015-2734-5 